\title{
Workplace characteristics and working class vote for the old and new right
}

Article

Accepted Version

Arndt, C. and Rennwald, L. (2017) Workplace characteristics and working class vote for the old and new right. British Journal of Industrial Relations, 55 (1). pp. 137-164. ISSN 0007-1080 doi: https://doi.org/10.1111/bjir.12143 Available at https://centaur.reading.ac.uk/73122/

It is advisable to refer to the publisher's version if you intend to cite from the work. See Guidance on citing.

To link to this article DOI: http://dx.doi.org/10.1111/bjir.12143

Publisher: Wiley

All outputs in CentAUR are protected by Intellectual Property Rights law, including copyright law. Copyright and IPR is retained by the creators or other copyright holders. Terms and conditions for use of this material are defined in the End User Agreement.

\section{www.reading.ac.uk/centaur}

\section{CentAUR}

Central Archive at the University of Reading

Reading's research outputs online 
Word count: 10.083 without abstract and this line and annotations for placement of figures and tables

\section{Workplace characteristics and working class vote for the old and new right}

This article focuses on the role of plant size for working class vote. We argue that workplace size does matter for political behaviour. Workers in smaller plants are less unionised and therefore base their voting decisions more strongly on their cultural attitudes, which undermines the support for social democratic parties. Using data from the European Social Survey (2002-2010), we find that workers in small plants have more right-wing attitudes and, consequently, vote for new and old right parties, contrarily to workers in larger plants. Our research points towards important structural explanations of working class support for the right and its cross-national differences. 


\section{Introduction}

The working class basis of radical right parties in Western Europe has been established in several studies over the last years (e.g. Carter 2005; Kitschelt 2007; Oesch 2008; Rydgren 2013). This phenomenon has been particularly puzzling since the working class has been traditionally viewed as social democracy's core clientele (e.g. Bartolini 2000). Moreover, several mainstream bourgeois parties have recently tried to broaden their voter base by working class votes. For instance, the Swedish Conservatives recently campaigned as 'Sweden's New Labour Party' (Oscarsson and Holmberg 2008: 68). The Danish Liberals have outperformed the Social Democrats in recent elections among working class voters (Stubager and Hansen 2013). Nevertheless, few studies have systematically analysed the competition between new right, old right and social democratic parties for working class votes (Arzheimer 2013; van der Brug et al. 2013). ${ }^{1}$

This article brings back a classical explanation on why workers turn right: plant size. ${ }^{2}$ The link between workplace size, the development of working class consciousness and political behaviour had been first particularly prominent in the Marxist tradition: Since large workplaces make the development of class consciousness easier, workers in larger plants should therefore display higher level of support for left-wing parties (for a critical review of this argument, see Pontusson, 1995). More generally, large plants have been considered as a fertile ground for unionisation. According to Oesch (2006: 172), "the size of the workplace in which people are employed is one of the most commonly cited factors affecting union membership".

These arguments are especially relevant for the overrepresentation of workers among the new right's electorate (e.g. Ivarsflaten 2005; Kitschelt 2007; Rydgren 2013) in a context of the decline of large manufacturing factories and de-unionisation. Outlining some electoral consequences of deindustrialisation, Pontusson (1995) showed that the employment share of large plants was positively correlated with social democratic parties' vote share. Accordingly, the decreasing share of large manufacturing plants and the restructuring of the economy towards smaller production units have become a structural disadvantage for social democratic parties.

Despite being often recognised as an important element for working class mobilisation, few studies have empirically tested the effect of plant size at the individual level (see the discussion by Pontusson 1995). Our article fills this gap and further explores the microfoundations of the plant size effect by looking at union coverage, workplace 
antagonisms, and political attitudes as mediators. Plant size is closely linked to unionisation: it is an important predictor of it. We focus primarily on plant size since it is antecedent to unionisation. By additionally analysing unionisation as a mediating variable, we get a better picture of the respective impact of both variables.

In a nutshell, we argue first that in small-sized workplaces, there is less antagonism between employer and employees than in larger ones. Similarly, workers in smaller plants are typically less unionised and more sceptical towards trade unions compared to their colleagues in larger plants (e.g. Bryson and Gomez 2005; Goss 1988; Oesch 2006: 172; Pontusson 1995). This then hampers the development of common economic interests among the workers in smaller plants and strengthens the effects of authoritarianism and scepticism towards immigration. It is postulated that unions would have a causal effect in muting antiimmigration attitudes (Lipset 1981). These effects finally foster right-wing vote choice among labour in smaller plants to the disadvantage of social democratic parties who fare better in larger unionised plants.

Our paper proceeds as follows. We first review the literature and develop our theoretical arguments and hypotheses. The next section presents the data and the methods used. Our analysis afterwards proceeds in two steps. On the basis of the European Social Survey (20022010), we first examine the effect of workplace size on political attitudes, and then on vote choice, in 16 European countries. We first find that employees and workers in smaller workplaces are more economically right-wing, as well as more authoritarian and restrictive on immigration. These effects are explained by fewer employer-employee antagonisms and lower union coverage at smaller workplaces. Second, we show that employees and especially workers in smaller plants indeed vote for the right, while their colleagues in larger plants support social democracy. We show further that this is caused by stronger effects of authoritarianism and restrictive view on immigration in smaller plants.

The findings have broad implications. The increasing capacity of right-wing parties particularly of new right parties - to get support among the core constituency of social democratic parties (working class) generally serves the expansion of the right block (see Bale 2003). Moreover, the weaker support among working class voters constitutes a powerful incentive for social democratic parties to renew their ideological profile in order to appeal to middle class voters. At the same time, weaker unions are less able to influence the political positioning of their traditional social democratic ally, who has now more leeway for programmatic changes. The analysis of parties' changing social bases undertaken in this 
article contributes to our understanding of the development of new political coalitions and majorities for public policies, and also for industrial relations.

\section{When do workers turn right and what is so important about workplace size?}

Political sociology had considered the role of workplace in the study of working class voting behaviour. Lipset's (1981) classic work posited that workers - although left-wing on socioeconomic issues - may vote for right-wing parties if mobilised on non-economic issues, e.g. law and order or traditionalism. This particularly concerned workers in non-unionised small plants (Lipset 1981: 261-278). British studies of the 1960s and early 1970s detected some mechanisms on why workers became "Working Class Tories". They argued that workers not being in a trade union, living in property houses, showing fidelity to their employers and identifying with the middle class were more likely to support the Conservative Party in the 1950s and 1960s (cf. Butler and Rose 1960; Butler and Stokes 1969, 1974; Goldthorpe et al. 1968; Nordlinger 1967). While this branch of literature on working class vote for the old right had been abandoned afterwards, some more recent works have elaborated the role of the workplace for social democracy's success among the working class.

First, Bartolini (2000: 158-159) demonstrated the crucial impact of the concentration of the working class for political mobilisation at the aggregate level. He found workplace size to be the most important socio-economic predictor of the left's electoral strength over one century. Second, Pontusson (1995) showed that the employment share of large plants was positively correlated with the vote share of social democratic parties. Pontusson (1995) also argued that the decreasing share of large plants and the restructuring of the economy towards smaller production units has become a structural disadvantage for social democratic parties. These studies illustrate that social democratic parties have more difficulties in mobilising the workforce in smaller plants and that the mechanisms distinguishing employees of small workplaces from those of bigger ones do materialise at the ballots.

These arguments have however not been further applied in the study of the new right since these parties gained ground at the expense of social democracy in many Western countries (Kitschelt 2007; Rydgren 2013). In the meantime, many studies have looked at the contextual conditions for the new right's breakthrough such as electoral systems, party organisation, party positions, or mainstream party behaviour, while there was some sense of consensus that the new right gets disproportionately high support among working class voters and the petty bourgeoisie (e.g. Carter 2005; Ivarsflaten 2005; Kitschelt 2007 Rydgren 2013). 
A key explanation why workers turn towards the far right has been immigration since workers harbour sceptical views on immigration matching the new right's agenda (e.g. Kitschelt 2007; Rydgren 2013). Accordingly, two types of class voting in line with Lipset's notion of working class authoritarianism co-exist in current party politics. One type, where some workers still stick to social democracy for economic reasons, and another type, where workers have turned right, and base their voting decision on non-economic issues, particularly immigration (e.g. Oesch 2013, Oesch and Rennwald, 2010). Despite the classic arguments on the importance of workplace size for workers turning right, it is striking that these have often been neglected in the study of the new right's electoral success and its cross-country variation.

Consequently, Kitschelt's (2013) discussion of the analyses in Rydgren's volume (2013) proposed to incorporate further factors such as occupational experiences, workplace characteristics or the mediating roles of unions and churches to get a more elaborated understanding of new right vote and its class base. ${ }^{3}$ The same goes for the more recent revival of "working class Toryism" in some countries where bourgeois parties compete at eye level with social democracy among workers. In light of the above, the next section establishes the theoretical microfoundation of the relationship between workplace size, attitudes and rightwing voting.

\section{Workplace size, political attitudes, and voting behaviour}

Arguing that the microfoundation of the link between workplace size and (non-)socialist vote have never been fully spelled out, Pontusson (1995: 499-503) proposed three mutually reinforcing causal mechanisms to link workplace size to social democracy's strength. The first relates to worker consciousness which is supposed to be more easily developed in larger plants. Pontusson emphasises two specific elements of large production units: the production is more capital-intensive and technologically interdependent than in small plants and the relations between employees are more impersonal. Conflicts of interest between workers and employers are therefore more transparent. The second relates to the costs of collective organisation which are lower in large production units. Economies of scale make union mobilisation in large plants more effective. The third one relates to the relative homogeneity of workers interests, which is likely higher in large plants.

These mechanisms can be linked to the discussion in the ER/IR literature on whether small firms are characterised by social harmony between employers and employees and larger ones by more antagonistic industrial relations (e.g. Goss 1988; Ingham 1970; Marlow \& 
Patton 1993; Moule 1998; Ram and Edwards 2003; cf. Blackburn 2005 for a review of the literature since 1970). While we are not able to solve this controversy, we outline the major arguments that account for the attitudinal linkage between small workplaces and right-wing vote choice.

As to the first mechanism, Ingham (1970) had argued that labour in smaller workplaces has a stronger identification with the employer/owner, while it has a more economic and materialist orientation towards work in larger workplaces. Later, Stephenson et al. (1983) showed that job satisfaction was higher in smaller firms and decreasing with size of the organisation. Moreover, higher job satisfaction led to a better image of the owner/management among the workforce (Stephenson et al. 1983: 38). These two early studies thus point towards less class consciousness and more harmonious relations in smaller businesses. Disputing this claim, Goss (1988) argued that smaller workplaces are not necessarily characterised by more harmonious industrial relations. In contrast, employees in smaller workplaces have simply an instrumental or pragmatic interest in the company's survival and their job security given the smaller capital base. They therefore co-operate and comply with the employer's demands (see also Marlow \& Patton 1993: 60). This means that diverging interests and employer-employee conflicts are not per se less present in small firms, but can be more effectively neutralised by employers (Goss 1988: 116). Either way, we have good reasons to argue that larger workplaces foster more class-conscious workers in contrast to smaller workplaces where less conflictive industrial relations prevail. This underpins Lipset's and Pontusson's macro-sociological link between workplace size and vote choice for social democratic or right-wing parties.

The second mechanism points to the role of unions. Plant size is important for and positively correlated with unionisation because workers in large plants are more likely to see their employers as adversaries and therefore join unions (e.g. Bryson et al. 2004; Bryson and Gomez 2005; Oesch 2006: 172; Pontusson 1995, 2013: 5). Similarly, economies of scale make union mobilisation in large plants more effective because recruitment costs per worker are lower in larger enterprises (Pontusson 1995: 500). In contrast, workers in smaller companies harbour more sceptical and contradictory attitudes towards trade unions since they regard trade unions to neglect the interests of the workforce in smaller businesses (Goss 1988: 123ff). Accordingly, involvement of trade unions in the small businesses' work routines are regarded as threat for their survival by both the employer and employees since the more bureaucratic and standardised routines that trade unions have implemented in larger plants cannot necessarily be adopted in smaller ones. Moreover, industrial action appears less in 
smaller establishments since the workforce is aware of the risk of closure given the smaller capital base (Goss 1988: 123ff; Marlow \& Patton 1993: 62). Weaker unionisation in smaller establishments implies lower saliency of issues related to industrial conflict and other economic matters such as state intervention or redistribution.

As to the political implications of workplace size and unionisation, Kitschelt (2013: 234) posited that unions dampen the workers' authoritarianism since union elites typically hold more liberal views on non-economic issues and do communicate these to their fellow members. Unions are therefore an important mediator in the relationship between workplace size, political attitudes and vote choice. Consequently, we expect that plant size affects the attitudes towards unions and state intervention.

Finally, the third mechanism points to the number of employees performing similar tasks or having some proximity in the type of work done. This increases the homogeneity of labour interests as well as the salience of these interests (Pontusson 1995: 499). Accordingly, Stephenson et al. (1983) argued and demonstrated that there are less stereotyped and negative views of the 'other' in smaller firms, while relationships in larger firms are more antagonistic and stereotyped. This difference is caused by the more frequent interpersonal relationships between people of different statuses in smaller workplaces and the division of labour in larger firms which increases within-group identification of people of similar occupational status. This should also foster more positive attitudes towards immigrant colleagues since these are of similar status in large firms and likely share the economic interests of their fellow colleagues given the daily interaction (e.g. Pettigrew 1998). With larger workplace size, the opinions about the alleged opponent become also more standardised and more distinct attitudes towards industrial relations develop (Stephenson et al. 1983: 39). In this regard, Moule (1998: 652) emphasised the importance of informal negotiation in small plants that tends to produce less collective consciousness and resistance among the workers given the more individualised and atomised personal relations.

The arguments from the ER/IR literature provide a more nuanced base for Lipset's argument that workers in smaller establishments have a higher propensity to vote for rightwing parties than their natural social democratic ally. Accordingly, we argue that fewer antagonisms in smaller workplaces strengthen the effects of authoritarianism to the benefit of right-wing parties. Authoritarianism is here understood as unquestioned obedience to authority and customs (see Kitschelt 2007: 1179). In contrast, the higher importance of economic preferences among workers in larger plants and their reinforcement through stronger unionisation benefits social democratic parties vis-à-vis their 
conservative/liberal/Christian democratic competitors. We add that workers are more confronted with immigrant colleagues of similar status in larger firms. This intragroup contact with immigrant colleagues reduces the scepticism towards immigration to the disadvantage of the new right party in larger firms since the perceived conflict with the owner/management is of higher relative importance. In contrast, the less frequent contact with foreign colleagues and the dampened industrial conflict in smaller firms should benefit the new right vis-à-vis social democracy. This is a functionally equivalent explanation for new right support which was not thoroughly conceptualised by Lipset's (1981), who implicitly focused on mainstream right parties.

Many arguments on workplace size had been initially developed for the manufacturing sector which typically included large plants. However, we do not see any reason why such arguments could not apply to all wage-earners. This is why the hypotheses on the political effects of plant size are developed for all employees. At the same time, we expect that workplace size has stronger effects for production workers.

We derive five testable hypotheses from our literature review:

H1: Employees in larger workplaces harbour more positive attitudes towards unions and state intervention since they perceive stronger antagonisms at the workplace

H2: Authoritarianism and scepticism towards immigration is stronger in smaller workplaces with less manifest workplace antagonisms

H3: Employees in larger workplaces are more likely to support social democratic parties relative to mainstream right and new right parties

H4: The effect of workplace size on voting choice is larger for production workers than for other classes

H5: The right vote choice of employees and production workers in small workplaces is explained by stronger effects of authoritarianism and scepticism towards immigration conditioned by unionisation

\section{Data and Methods}

We use the European Social Survey (ESS) (2002-2010) to test our arguments that workplace size affects the attitudes and voting behaviour of employees and workers. ${ }^{4}$ The ESS provides the best data for our purpose since it contains the ISCO88 codes to construct Oesch's (2006, 
2008) class scheme, the respondent's workplace size and a battery of other structural variables. We use 16 countries that have established a lasting democratic tradition and experienced the challenge of deindustrialisation since the 1970s, a period in which the first new right parties made their breakthrough. ${ }^{5}$

In all analyses we obtained workplace size through the item: "Including yourself, about how many people are/were employed at the place where you usually work/worked?". This is an ordinal variable distinguishing five categories "under 10", "10-24”, “25-99”, “100-499”, and "500 or more". This is the best operationalisation of workplace size in comparative datasets, although the exact number of employees or an interval coding would be preferable for our purpose (see Bryson et al. 2004 for a similar operationalisation). To examine whether the effect of workplace size on voting choice is larger for production workers than for other classes we interacted the production worker dummy with workplace size.

We apply multilevel linear and logistic regression models because we have variation at the micro-level and macro-level and because the respondents in ESS are nested within countries (or election years) that differ considerably in their industry structure. Multilevel models are adequate for analysing hierarchical or nested data to provide accurate estimates of standard errors and taking intra-class correlations into account (e.g. Rabe-Hesketh and Skrondal 2012). We included a random intercept at the country level and a random coefficient for plant size at the country level. In case of the multilevel logit models, our rationale is to account for country-specific idiosyncrasies in the strength of bourgeois and new right parties by allowing the constant to vary across countries (our random intercept) and to control for country-specific idiosyncrasies of the plant size effect by estimating its variance across countries (our random coefficient for plant size). We do not introduce a covariance between the random intercept and the random coefficient since these covariances remained insignificant in further model specifications.

Our analysis proceeds in two steps. First, we use the ESS' first round and apply a multilevel linear regression model. Here we include the independent variables of interest stepwise to tap into the causal relationship between workplace size and political attitudes. The rationale is to show that small workplaces have less antagonistic relations between employers and employees and are also less unionised which leads their employees to develop more economically and culturally right-wing attitudes. We use attitudes towards trade unions and state intervention to capture economic attitudes and indices for authoritarianism and attitudes towards immigration to capture cultural attitudes. ${ }^{6}$ The two economic items ask "The less that government intervenes in the economy, the better it is for [country]" and "Employees need 
strong trade unions to protect their working conditions and wages" on a scale from " 1 Agree strongly' to '5 Disagree strongly'.

Our analysis here is limited to the ESS' first round since this rotating module consists of an item that captures workplace antagonisms: "During the last 12 months, how satisfied or dissatisfied have you generally been with the way things have been handled in your work or workplace?" This item is an important mediator variable of the workplace size effect and measured on an 11-point scale ranging from '0 Extremely dissatisfied' to '10 Extremely satisfied'. While this item does not explicitly ask respondents about relationships between the management and the workforce, it is the best available item on workplace antagonisms in recent cross-national surveys given that we need data that consist of both an item on workplace antagonism and workplace size. These two variables are only jointly available in the ESS' first round restricting the selection of further explanatory or control variables. Particularly, a variable that explicitly refers to employers and employees would be desirable.

The second important mediator variable in this first step is union membership at the individual level, respectively union presence at the respondents' workplace. According to the theoretical arguments made above, unionisation is an important mediator of the effect of plant size on political attitudes. The same goes for the presence of immigrant colleagues at the respondent's workplace which is expected to dampen sceptical attitudes towards immigration. We therefore expect that the inclusion of our measures of workplace antagonism, union presence, and immigrant colleagues reduces and explains the workplace size effect.

Another main independent variable is class. We employ Oesch's class scheme in its eight class version to distinguish classes according to their work logic in post-industrial labour markets (Oesch 2006, 2008). Oesch's class scheme accounts for the tertiarisation of employment structure, welfare state expansion, occupational upskilling and the increasing heterogeneity of middle class professions. These are crucial factors for the formation of political preferences and vote choice for distinct party families (Kitschelt 1994: 17; Oesch 2006: 61-64; Oesch 2008: 336). We focus particularly on production workers who had been social democracy's traditional core constituency, but increasingly been the backbone of the new right and a new target group for some old right parties (Kitschelt 2007; Oesch 2008).

Further controls at the individual level are age (in years), gender, and education. Education is an important predictor in the vote choice for new right parties and we therefore inspect whether the effects of workplace size are caused by the lower education of the labour force in smaller workplaces. This is a likely effect since larger workplaces are typically more capital-/skill-intensive which requires a better educated workforce. We cannot control for 
public-private occupations since this variable is lacking in the early rounds of the ESS. This makes it impossible to include public-private occupations in our first step of the analysis, and would to lead to the loss of 39058 observations out of our 58782 observations in our second step, where we analyse party choice.

The second step of our analysis examines whether the workforce in small workplaces prefers the old and new right to social democracy. Our dependent variable here is party choice, where the respondents were asked which party they voted for in the last national election. We focus on the contrast of social democratic party versus new right party and social democratic party versus the largest old right party, respectively. These parties are the main contenders among production workers and where the workplace size effect should materialise. We therefore distinguished these three party families (see Table A1 in the appendix for the classification of the respective parties). ${ }^{7} \mathrm{We}$ again use a stepwise model building to show first that employees in small workplaces turn to right-wing parties. We then include the interaction production worker*workplace size to test whether production workers in small plants particularly vote for the right. Afterwards we control for union membership, authoritarianism, attitudes towards immigrants and finally introduce three-way interactions union membership* workplace size*cultural attitudes. The latter inspects whether the effect of rightwing attitudes on vote choice is strongest among workers in smaller workplaces and moderated through union membership.

\section{Analysis}

\section{Workplace size and political attitudes}

We first present the analysis that taps into the mechanisms of working in a small plant and having right-wing attitudes. Table 1 presents the results of the multilevel linear regression models with the four dependent variables. Models 1-3 inspect our claim that labour in smaller workplaces harbours more sceptical views towards unions. The first model shows that working at a smaller workplace is indeed significantly connected with more negative evaluations of trade unions. The larger their workplace, the more respondents agree with the statement that employees need strong trade unions (Hypothesis 1). Model 2 and 3 demonstrate that this effect is explained by the less antagonistic relationships in smaller workplaces and the stronger organisation at larger workplaces. The more satisfied wage-earners are, the less they perceive a need for trade unions and this is a particular phenomenon at smaller workplaces (see Table A2). Similarly, the more organised the labour force is, the more it 
regards unions as necessary, and this goes for both measures of trade union presence (Model 2 and 3$)$.

\section{[TABLE 1 ABOUT HERE]}

A similar but weaker relationship between workplace size and attitudes towards state intervention can be seen in Models 4-6. Model 4 shows a significant positive effect of workplace size on support for government intervention, which indicates that workers in smaller workplaces harbour more economically conservative attitudes. This effect is again mediated by satisfaction with the workplace conditions and especially union membership/presence as Models 5 and 6 show. Being a union member or having a trade union at the workplace makes respondents more supportive of government intervention. This explains the workplace size effect from Model 4 that has now halved and become insignificant. The analysis confirms that unions affect the attitudes of the workforce and increase the effects of economic issues in larger workplaces where the labour force is less satisfied with the working conditions. In contrast, labour in smaller workplaces is less supportive of government intervention since it perceives less employee-employer conflicts and unions are more weakly organised.

The results of Models 1-6 prove our first hypothesis that less antagonisms and weaker unionisation in smaller workplaces lead to more sceptical attitudes towards trade unions and government intervention, while labour in larger workplace holds more traditional left-wing economic attitudes. Moreover, it corroborates our arguments that conflicts are more transparent in larger workplaces and effectively channelled by unions.

Next, we examine the interrelation between workplace size and cultural attitudes by deploying our two indices as dependent variables. Models 7-9 reveal that authoritarianism is not directly influenced by workplace size. The non-significant coefficient for authoritarianism goes against our Hypothesis 2, but is in line with our descriptive analysis in Table A2 where authoritarianism does not differ across workplace size. The effect, however, is indirect since the inclusion of satisfaction with working conditions reveals the underlying pattern that connects workplace size to authoritarianism. Model 8 shows that being satisfied with the working conditions is associated with more authoritarian viewpoints. Since the workforce in smaller workplaces is more satisfied with the working conditions, we have found the attitudinal link in the relationship between plant size and working class authoritarianism that Lipset (1981) had established. This is confirmed when interacting our antagonism measure 
with workplace size. The constitutive term for antagonism - now capturing its effect for small firms - doubles from 0.33 to 0.60 . The interaction is significant and of negative sign which means that the effect of being satisfied with the working conditions on being more authoritarian decreases with plant size. This is an indirect proof that cultural issues have stronger effects in smaller workplaces, while economic issues have stronger effects in larger workplaces. The stronger perceptions of antagonisms among the workforce of larger establishments dampen the effect of authoritarianism.

A similar pattern of mediation is visible if we use attitudes towards immigration as last dependent variable in Models 10-12. Model 10 reveals significantly more liberal views on immigration in larger workplaces first. This is explained by the more frequent contact with immigrants in Model 11 since the workplace size effect washes completely out after controlling for this variable. Moreover, the results of Model 12 indicate that smaller workplaces without immigrants produce outright scepticism towards immigrants, while the presence of foreign colleagues leads to more liberal attitudes. The interaction workplace*immigrant colleagues is significant and negative which indicates that the effect of having foreign colleagues on liberal views towards immigrants decreases with plant size. Furthermore, the constitutive term for immigrant colleagues - now measuring the effect in small workplaces only - has increased to 9.36 in M12. These results suggest that cultural effects are stronger in small plants and provide first evidence for Hypothesis 5.

Finally, we briefly comment on the control variables in these analyses. The class variable yields that production workers are most authoritarian and most sceptical towards immigration and government intervention. Similar patterns exist for office clerks and service workers. The reference category socio-cultural specialist is usually the most left-wing class on all four items and clearly favours state intervention and immigration. Males are less authoritarian and sceptical towards immigration, but also less in favour of trade unions and government intervention. Since men normally harbour more right-wing attitudes in electoral research, one should consider that we controlled for a couple of other predictors that are connected to authoritarianism and sceptical attitudes towards immigration. Age is positive related to being more authoritarian and restrictive on immigration while its effect on economic attitudes is very modest. Higher and especially tertiary education is associated with less authoritarianism, more liberal views on immigration, more support for state intervention, but also a negative viewpoint on trade unions compared to the reference category less than upper secondary education. 


\section{Workplace size and vote choice}

Having established the mechanisms of workplace size and political attitudes, we now inspect whether employees and workers of small workplaces prefer the old and new right to social democracy and whether this can be explained by their more right-wing attitudes which we analysed above. We restrict this analysis to authoritarianism, immigration attitudes and union membership as mediators since the cumulative data set does not include workplace antagonisms and attitudes towards trade union or government intervention (which is only available in the ESS I).

Table 2 presents the results of the multilevel models for the effect of the workplace size on vote choice with social democratic parties as reference category. ${ }^{8}$ First, we run a simple multilevel logit model with class, workplace size, age, gender, and education (Model 1) to inspect whether employees of small workplaces turn towards the right and to which extent the party families differ in their voter base. Model 1 yields that production workers - together with two employer categories - are the backbone of the new right's electoral support. Their coefficients are highly significant and have the expected sign. In contrast to the new right, the old right does not outperform the social democrats among production workers since the coefficient is negative and significant. This is not surprising as production workers have only recently become an explicit target group for some mainstream bourgeois parties.

Crucially for our argument, the workplace size variable yields a significant negative effect on the choice to prefer old and new right parties to social democratic ones. The larger their workplace, the less do workers vote for right-wing parties vis-à-vis social democratic parties. Notably, the effect of the workplace size for mainstream bourgeois parties is somewhat stronger than for the new right. This provides evidence for our third hypothesis that workplace size affects vote decisions since employees of larger plants favour social democratic parties, while their colleagues in small-sized plants favour both the new and old right. The three demographic controls correspond to previous findings from electoral research. Younger respondents prefer the new right to social democrats, while older respondents have a tendency to prefer the old right. Males do significantly prefer both right party families to social democrats and particularly the new right. Voters with tertiary education prefer social democracy over the new right, whereas bourgeois parties perform significantly better among voters with higher (more than upper secondary) education compared to social democracy. Since the results for these three controls stay virtually the same for all models examined, we do not comment on them in the following models. 


\section{[TABLE 2 ABOUT HERE]}

Model 2 tests our fourth hypothesis that the plant size effect is particularly strong among production workers by introducing the interaction production worker*workplace size. ${ }^{9}$ The constitutive terms for the respective variables yield first that the effect for production workers (now only those in small workplaces) on the vote for the new right has increased compared to previous models. Similarly, the coefficient contrasting mainstream bourgeois parties and social democrats among production workers has changed sign, but remains significant. Accordingly, production workers in smaller workplaces significantly prefer the old right over social democratic parties. The constitutive term for workplace size (now for all classes except production workers) has decreased and become insignificant in case of the new right. The effect of the workplace size shown in Model 1 is therefore largely attributable to productions workers as we stated in Hypothesis 4.

Moreover, the interactions production worker*workplace size in Model 2 are both negative and significant at conventional levels which means that the support for the new and old right vis-à-vis social democracy among production workers declines as workplace size increases. The interaction effects are also stronger than the constitutive terms for workplace size from the same model and the coefficients for workplace size from Model 1. This provides further evidence for Hypothesis 4 that establishment size matters especially for the vote choice of production workers.

Next, Model 3 controls whether the effects of the workplace size are caused by unionisation - an important mediator in our first step of the analysis. As expected, union members significantly prefer social democratic parties to new and old right parties. Crucially, controlling for union membership diminishes the effects of workplace size. When compared to Model 1, the constitutive term for plant size in Model 3 washes almost completely out for the new right and halves in size for the old right. The constitutive term for the vote choice of production workers for the old right in Model 3 also losses strength and significance compared to Model 2. The effects of the workplace size that we found in Models 1 and 2 are therefore partly attributable to union membership as argued in the literature (e.g. Oesch 2006; Pontusson 1995). However, the interaction production worker*workplace size reduces only mildly and stays significant after we control for union membership in Model 3. This means that workplace size has still an independent effect on voting among production workers which confirms our fourth hypothesis once more even when we control for unionisation. 
A next step was to include indices for authoritarianism and attitudes towards immigration (Model 4). This tests our fifth hypothesis that right-wing support in smaller workplaces can be explained by stronger effects of authoritarianism and immigration conditioned by unionisation. To inspect the common explanations for the vote choice for these two party families and to save space, we use our immigration index in Model 4 for the new right and the index of authoritarianism in Model 4 for the old right as additional independent variables.

The respective coefficients of Model 4 show that particularly the vote choice of production workers in small plants for the new right can be explained by their right-wing attitudes. The constitutive term for production workers (those in small plants) in Model 4 reduces for both right-wing parties after introducing our two indices of right-wing cultural attitudes when compared to the respective coefficients in Model 3. The coefficients for the two indices confirm our expectations further since being more authoritarian and restrictive towards immigration significantly benefits both types of right-wing parties. ${ }^{10}$

In contrast, the interaction terms for production workers and workplace size remain almost unchanged and still significant. This means that workers in smaller plants favour both right-wing party families in contrast to social democratic parties even if we control for rightwing attitudes. On the other hand, the larger the plant of a production worker, the more likely (s)he supports social democratic parties.

To inspect the moderating role of unions, we finally interacted union membership with plant size and the two indices. We thus examine whether authoritarianism and attitudes towards immigration have stronger effects on vote choice in smaller plants and what role unions play for the translation of right-wing attitudes into vote choices. To save space and keep the analysis and figures parsimonious, we decided to contrast social democratic parties with both right-wing party families and report the findings in Model 5. Since three-way interactions (and their significance) from multilevel logit models are not easily interpretable, we calculated the predicted probabilities for voting a social democratic party across the range of the two indices for three illustrative conditions.

Figure 1 shows that unions play a strong role in moderating the effect of authoritarianism on vote choice for right-wing versus social democratic parties and demonstrates that unionisation accounts for a large part of the plant size effect. The slopes in Figure 1 yield the strongest effects of authoritarianism on right-wing vote choice among nonunionised workers in smaller plants, while the effects of authoritarianism are weaker among union members in both very small and very large plants. All three types of workers support 
social democracy with a probability of around 70 per cent if they harbour libertarian attitudes (left-hand side of Figure 1). Moving towards more authoritarianism values affects right-wing vote choice most effectively among non-unionised workers in small plants. Their differences to unionised workers become significant when our index exceeds values of 55, a value where the support for social democracy also drops below 50 percent. In contrast, the probability of voting social democracy stays always above 50 percent among unionised workers (in both small and large firms), even if they harbour very authoritarian values (right-hand side of Figure 1). This result confirms that unions dampen working class authoritarianism to the benefit of social democratic parties. Authoritarianism works most effectively in favour of right-wing parties among non-union members who are most common in small firms. In this respect, we found evidence that the weaker unionisation in smaller plants accounts for a considerable part of the workplace effect and thus mutes the strength of cultural issues (Hypothesis 5).

\section{[FIGURE 1 AND 2 ABOUT HERE]}

Similar but somewhat weaker and not always significant patterns can be observed for immigration (Figure 2). Union membership moderates the effects of attitudes towards immigration on vote choice and accounts for a substantial part of the workplace size effect. First, when holding the most restrictive attitudes (left-hand side of Figure 2), non-unionised workers in small plants (black line) are least likely to support social democracy and this is significantly different to unionised workers in larger plants (blue line). This difference remains significant until the scale reaches 70 (the scale runs from ' 0 most skeptical' to ' 100 most liberal'). This indicates stronger effects of immigration on vote choice in small businesses with weaker unionisation. Second, the slope for unionised workers in small firms (red line) across the index for immigration deserves attention. Unionised workers in small firms with very restrictive attitudes have a similar probability in supporting social democracy vis-à-vis right-wing parties compared to their non-unionised colleagues (left-hand side of Figure 2). However, the farther we move towards liberal attitudes, the stronger the tendency of unionised workers in small companies to support social democracy compared to their nonunionised colleagues. Unionised workers in small companies approach the voting behaviour of union members in large firms if the index exceeds 50. Restrictive attitudes on immigration therefore turn most effectively into right-wing vote choice among non-unionised workers of small firms. In contrast, our results demonstrate that unions are a decisive force to mute the 
effects of immigration to the benefit of social democracy. Accordingly, the patterns in Figure 2 complement our evidence for Hypothesis 5 as the stronger effects of cultural issues on vote choice in smaller firms are conditioned (and thus explained) by unionisation.

\section{Conclusion}

This article examined the role of workplace size for political attitudes and the support of working class voters for new and old right parties vis-à-vis social democratic parties. While the strength of the new right among production workers is well-documented (Kitschelt 2007), there is still limited knowledge on which type of working class voters turns right and thus still some unexplained cross-country variation in the support of working class voters for the new right. The same goes for some mainstream right-wing parties that in some countries successfully broadened their voter base by competing for working class voters. We argued that the success of old and new right parties is contingent on the workplace size as smaller plants produce less antagonistic relationships between employers and employees, whereas larger plants have more adversary relationships, while collective mobilisation through unions is easier here. Drawing on arguments from classical political sociology and ER/IR scholarship on the role of the workplace for working class support for the right, we expected that workplace size affects the vote of workers for the old and new right compared to their traditional ally, the social democrats.

As summarised in Table 3, our hypotheses at the micro-level were largely confirmed as employees in smaller workplaces with less employer-employee antagonisms harboured more right-wing attitudes and preferred the two right-wing party families to social democratic parties, while social democrats enjoy increasing support among labour as plant size grows. Furthermore, this effect is particularly virulent among production workers and the effects of right-wing attitudes are stronger among the labour force in smaller workshops and weaker in larger plants. This is explained by the stronger unionisation in larger plants which reduces the effects of authoritarianism and immigration on voting for right-wing parties. In this respect, the weaker antagonism found in smaller workplaces hampers unionisation and makes vote choices based on cultural issues more likely, which confirms Kitschelt's (2013: 234) claim.

[TABLE 3 ABOUT HERE] 
The article has focused on plant size, a variable that has been assumed to have important effects for the relationships between workers and employers and for collective action. By focusing on this variable, we investigated how the very basic structure of a workplace affects political attitudes and matters for voting choice. In an effort of elucidating the microfoundations of plant size effect, our analysis has shown the decisive role played by unionisation which reduced the plant size effect in various models. However, this should not be a reason for completely dismissing the influence of plant size. One can argue that plant size is the first variable to consider in a causal path, since it is antecedent to unionisation. Yet, more complex interactions between plant size and unionisation are also possible. Unionisation could precede plant size, when for example plant restructuring occurs because the workforce is unionized. Without having completely disentangled these effects, our findings have some important implications for the importance of plant size and unions in electoral behaviour.

First, the article sheds light on the difficulties and opportunities for political parties to gain support among workers in contexts where large factories do no longer dominate the industrial landscape. Unionised workers are more likely to support social democratic parties than mainstream right-wing parties or new right parties. Consequently, in times of weaker unionisation, social democratic parties are less able to mobilise their historical core constituency, i.e. the working class. The presence of small plants and the corresponding low level of unionisation will therefore permit right-wing parties to gain ground inside the working class with a culture based appeal. Without the presence of unions who insure the importance of economic issues, workers in smaller plants are more likely to consider cultural issues more important for their vote choice. De-unionisation might be well a decisive element for the phenomena of electoral dealignment and realignment that many Western European countries have faced since the 1970s.

Second, and in a comparative perspective, we believe that our findings contribute to the understanding of favourable context conditions for the new right and its emergence. If workplace size has an effect on workers' political attitudes and their voting behaviour, then it follows that countries with an industry structure characterised by a high share of small and medium-sized plants provide a favourable context for the establishment and electoral performance of the new right. In contrast, countries with the dominance of big companies/workplaces constitute a more difficult terrain for the new right.

Third, further analysis should dig deeper in the mechanisms and should add both dynamic aspects and aggregate level data on the industry structure. Analysing longer time spans with data of sufficient quality would also permit to analyse the effects of 
deindustrialisation and industrial restructuring on the relationship between class, workplace size, unionisation and vote choice over time. Moreover, combining high quality data on the industry structure with individual level survey data would shed more light on contextual factors for the competition between mainstream bourgeois, social democratic, and far right parties. Similarly, it would add further evidence on the relationship between workplace size and right vote that we tried to establish in this paper. 
${ }^{1}$ We use the term old right to denote mainstream liberal, conservative and in some countries Christian democratic parties. We use the term new right to denote parties that the literature typically labels as extreme right, populist right or radical right.

${ }^{2}$ We use the terms plant, workplace and workshop interchangeably.

${ }^{3}$ When unionisation has been taken into account, this has not lead to clear findings. For example, Bornschier and Kriesi (2013) show that skilled unionised workers are less likely to vote for the new right, but not unionised routine operatives, while Oesch (2008) finds a negative but weak impact of union membership on voting for new right parties.

${ }^{4}$ The European Social Survey can be accessed at http://www.europeansocialsurvey.org/, where further material for documentation is available.

${ }^{5}$ We use data for Austria, Belgium, Denmark, Finland, France, Germany, Great Britain, Ireland, Italy, Luxembourg, the Netherlands, Norway, Portugal, Spain, Sweden, and Switzerland.

${ }^{6}$ We created the index for authoritarian attitudes using the variables "impsafe", "ipfrule", "ipstrgv", "ipbhprp", and "imptrad" from the item battery on traditionalism/authoritarianism in the European Social Survey. The index goes from 0 (most libertarian) to 100 (most authoritarian) with a Cronbach's Alpha of 0.7231 . The index on immigration was created from the item battery on attitudes towards immigration/immigrants in each ESSround and contains six variables ("imbgeco", "imueclt", "imwbcnt", "imsmetn", "imdfetn" and "impcntr"). The index goes from 0 (most restrictive) to 100 (most liberal) with a Cronbach's Alpha of 0.8257 . See the online appendix for further information.

${ }^{7}$ If parties form electoral cartels alliances, they are grouped in the same family, e.g. the Flemish Labour and Walloon Socialist Parties are grouped as Belgian Social Democrats.

${ }^{8}$ We performed various robustness and sensitivity tests of our models such running the same models with election years as clusters. Some of these exemplary models appear in the online appendix of this article.

${ }^{9}$ We are aware that logit coefficients from different models are not fully comparable (Mood 2010). We therefore inspected the predicted probabilities of all models run and also ran linear probability models as alternative specification suggested by Mood (2010: 78f). These yield similar patterns as our logit coefficients and we therefore stick to the presentation of the logits in Table 2 (see Figure A1 in the online appendix for a visual inspection of Model 3 for the bourgeois parties).

${ }^{10}$ Replacing the indices with each other in the models yields a similarly strong and highly significant effect of authoritarianism to prefer the new right versus social democracy, whereas the effect of immigration to prefer the old right is only -0.015 but still highly significant. 


\section{References}

Arzheimer, K. (2013). 'Working-class Parties 2.0? Competition between Centre-left and Extreme Right Parties'. In J. Rydgren (ed.). Class Politics and the Radical Right. Routledge: London \& New York, pp. 75-90.

Bale, T. (2003). 'Cindarella and Her Ugly Sisters: The Mainstream and Extreme Right in Europe’s Bipolarising Party Systems’. West European Politics, 26: 67-90.

Bartolini, S. (2000). The Political Mobilization of the European Left, 1860-1980. The Class Cleavage. Cambridge: Cambridge University Press.

Blackburn, R. (2005). 'Researching the Employment Relationship in Small Firms'. In S. Marlow, D. Patton and M. Ram (eds.), Managing Labour in Small Firms. New York, Routledge, pp. 43-65.

Bornschier, S. and Kriesi, H. (2013). 'The Populist Right, the Working Class, and the Changing Face of Class Politics'. In J. Rydgren (ed.), Class Politics and the Radical Right. Routledge: London \& New York, pp. 10-29.

Bryson, A., Cappellari, L. and Lucifora, C. (2004). 'Does Union Membership Really Reduce Job Satisfaction?’ British Journal of Industrial Relations, 42: 439-459.

— and Gomez, R. (2005). 'Why Have Workers Stopped Joining Unions? The Rise in NeverMembership in Britain'. British Journal of Industrial Relations, 43: 67-92.

Butler, D. and Rose, R. (1960). The British General Election of 1959. London: Macmillan.

— and Stokes, D.E. (1969). Political Change in Britain: Forces Shaping Electoral Choice. London: Macmillan.

— and Stokes, D.E. (1974). Political Change in Britain: the Evolution of Electoral Choice. London: Palgrave Macmillan.

Carter, E. (2005). The Extreme Right In Western Europe. Manchester: Manchester University Press. 
European Social Survey Cumulative File, ESS 1-5 (2012). Data file edition 1.0. Norwegian Social Science Data Services, Norway - Data Archive and distributor of ESS data. Bergen: Norwegian Social Science Data Services.

Goldthorpe, J.H., Lockwood, D. et al. (1968). The Affluent Worker: Political Attitudes and Behaviour. Cambridge: Cambridge University Press.

Goss, D.M. (1988). 'Social Harmony and the Small Firm: A Reappraisal'. Sociological Review, 36: 114-132.

Ingham, G.K. (1970). Size of Industrial Organization and Worker Behaviour. Cambridge: Cambridge University Press.

Ivarsflaten, E. (2005). 'The Vulnerable Populist Right Parties: No Economic Realignment Fuelling their Electoral Success'. European Journal of Political Research, 44: 465-92. Kitschelt, Herbert (1994). The Transformation of European Social Democracy. New York: Cambridge University Press.

— (2001). 'Politische Konfliktlinien in westlichen Demokratien: Ethnisch-kulturelle und wirtschaftliche Verteilungskonflikte'. In D. Loch and W. Heitmeyer (eds.), Schattenseiten der Globalisierung. Rechtsradikalismus, Rechtspopulismus und separatistischer Regionalismus in westlichen Demokratien. Frankfurt: Suhrkamp, pp. 418-442.

— (2007). 'Growth and Persistence of the Radical Right in Postindustrial Democracies: Advances and Challenges in Comparative Research'. West European Politics, 30: 1176-1206.

— (2013). 'Social Class and the Radical Right: Conceptualizing Political Preference Formation and Partisan Choice'. In J. Rydgren (ed.), Class Politics and the Radical Right. Routledge: London \& New York, pp. 224-251. 
Lipset, S.M. (1981) [1960]. Political Man. The Social Bases of Politics. Baltimore: Johns Hopkins University Press.

Marlow, S. and Patton, D. (1993). 'Managing the Employment Relationship in the Smaller Firm: Possibilities for Human Resource Management'. International Small Business Journal, 11: 57-64.

Mood, C. (2010). 'Logistic Regression: Why We Cannot Do What We Think We Can Do, and What We Can Do About It. European Sociological Review, 26: 67-82.

Moule, C. (1998). 'Regulation of Work in Small Firms: A View from the Inside'. Work, Employment \& Society, 12: 635-653.

Nordlinger, E.A. (1967). The Working Class Tories: Authority, Deference and Stable Democracy. London: MacGibbon \& Kee.

Oesch, D. (2006). Redrawing the Class Map. Stratification and Institutions in Britain, Germany, Sweden and Switzerland. Houndmills: Palgrave MacMillan.

_ (2008). 'Explaining workers' support for right-wing populist parties in Western Europe: Evidence from Austria, Belgium, France, Norway and Switzerland'. International Political Science Review, 29: 349-373.

— (2013). 'The class basis of the cleavage between the New Left and the radical right. An analysis for Austria, Denmark, Norway and Switzerland'. In J. Rydgren (ed.), Class Politics and the Radical Right. Routledge: London \& New York, pp. 31-51.

— and Rennwald, L. (2010). 'The Class Basis of Switzerland's Cleavage Between the New Left and the Populist Right'. Swiss Political Science Review, 16: 343-372.

Oscarsson, H. and Holmberg, S (2008). Regeringsskifte Väljarna och Valet 2006. Stockholm: Norstedts Juridik.

Pettigrew, T.F. (1998). 'Intergroup Contact Theory'. Annual Review of Psychology, 49: 6585. 
Pontusson, J. (1995). 'Explaining the Decline of European Social Democracy: The Role of Structural Economic Change'. World Politics, 47: 495-533.

— (2013). 'Trade Unions and Redistributive Politics'. University of Geneve, Working Paper.

Rabe-Hesketh, S. and Skrondal, A. (2012). Multilevel Model and Longitudinal Modeling Using STATA. Third Edition. College Station: Stata Press.

Ram, M. and Edwards, P. (2003). 'Praising Caesar Not Burying Him: What We Know about Employment Relations in Small Firms'. Work, Employment \& Society, 17: 719-730.

Rydgren, J. (2013). Class Politics and the Radical Right. Routledge: London \& New York.

Stephenson, G., Brotherton, G.D., Delafield, G. and Skinner, M. (1983). 'Size of Organisation, Attitudes to Work and Job Satisfaction'. Industrial Relations Journal, 14: $28-40$.

Stubager, R. and Hansen, K.M. (2013). 'Social Baggrund og Partivalg. In R. Stubager, K.M. Hansen and J.G. Andersen (eds.), Krisevalg. Økonomien og Folketingsvalg 2011. København: Jurist- og Økonomforbundets Forlag, pp. 61-88.

Van der Brug, W., Fennema, M., de Lange, S. and Buller, I. (2013). 'Radical Right Parties. Their Voters and their Electoral Competitors'. In J. Rydgren (ed.), Class Politics and the Radical Right. Routledge: London \& New York, pp. 52-74. 
TABLE 1

Effects of class, unionisation and workplace size on attitudes towards government intervention, unions, authoritarianism and immigration, 2002 in sixteen Western countries

Need for trade unions: higher Government intervention: higher Authoritarianism: higher values Attitudes towards immigrants, index:

values indicate disagreement_ values indicate higher support indicate more auth.

higher values mean more liberal

$\begin{array}{lllllllllllll}\text { M1 } & \text { M2 } & \text { M3 } & \text { M4 } & \text { M5 } & \text { M6 } & \text { M7 } & \text { M8 } & \text { M9 } & \text { M10 } & \text { M11 }\end{array}$

Individual level

Class (reference category: Socio-cultural specialists)

$\begin{array}{llll}\text { Traditional bourgeoisie } & 0.17 & 0.03 & 0.17\end{array}$

Technical specialists

$0.17 \quad 0.03 \quad 0.17$

$\begin{array}{lll}-0.20 & -0.25 & 5.67\end{array}$

$0.22 * * * \quad 0.15 * * *$

$0.16^{* * *}$

$-0.18 * * *$

$-0.16 * * *$

$-0.17 * * *$

0.27

5.57

5.48

$-1.44 *$

$-1.61^{*}$

$-1.66^{*}$

Managers

$0.40 * * * \quad 0.30 * * * \quad 0.34 * * *$

$-0.14 * * *$

$-0.12 * * *$

$-0.13 * * * 1.02$ !

0.29

0.26

$-4.30 * * *$

$-4.51 * * *$

Petite bourgeoisie

0.31 !

0.18

0.28

$-0.25$

$-0.21$

$-0.25$

$-2.78$

1.00 !

$1.00 !$

$-2.62 * * *$

$-2.72 * * *$

$-2.69 * * *$

Production workers

$-0.03$

$-0.07 *$

$-0.26 * * *$

$-0.25 * * *$

$0.25 * * *$

$3.08 * * *$

$3.06 * * *$

$-4.90 * * *$

$-4.80 * * *$

Office clerks

$0.17 * * * \quad 0.10 * *$

$0.13 * * *$

$-0.16^{* * * *}$

$-0.14 * * *$

$-0.15 * * *$

$1.72 * *$

$1.74 * *$

$1.72 * *$

$-8.12 * * *$

$-8.06 * * *$

Service workers

0.00

$-0.06^{*}$

$-0.04$

$-0.20 * * *$

$-0.18 * * *$

$-0.19 * * * \quad 2.62 * * *$

$2.64 * * * \quad 2.61 * * *$

$-4.20 * * *$

$-4.00 * * *$

$\begin{array}{lll}0.09 * * * & 0.10 * * * & 0.10 * * *\end{array}$

$-0.04 *$

$-0.04 *-0.05 *$

$-1.60 * * *$

$1.59 * * *$

$5.29 * * *$

$5.28 * * *$

$-5.26 * * *$

Age

$\begin{array}{lll}0.00 & 0.00 * * * & 0.00 \text { ! }\end{array}$

$-0.00 *$

$-0.00 * * \quad-0.00$ !

$0.19 * * *$

$0.18 * * *$

$0.18 * * *$

$1.23 * * *$

$1.06 * * * \quad 1.04 * * *$

Education (reference category: less than upper secondary)

Upper secondary

$0.08 * * * \quad 0.11 * * * \quad 0.10 * * *$

$0.11 * * *$

$0.11 * * * \quad-0.80 !$

-0.76 !

-0.76 !

$-0.10 * * *$

$-0.08 * * * \quad-0.08 * * *$

Post-secondary

$0.22 * * * \quad 0.23 * * * \quad 0.23 * * *$

$0.19 * *$

$0.19^{* *}$

$0.18 * * \quad-1.53$

$-1.50$

$-1.52$

$2.88 * * *$

Tertiary

$0.25 * * * \quad 0.27 * * * \quad 0.26 * * *$

$0.21 * * *$

$0.21 * * *$

$0.21 * * *$

$-3.99 * * *$

$-3.92 * * *$

$-3.92 * * *$

$4.89 * * *$

$4.66 * * *$

Union member

$\begin{array}{lll} & -0.45 * * * & \\ -0.04 * * * & -0.01 * & -0.00 \\ & 0.02 * * * & 0.02 * * *\end{array}$

$0.11 * * *$

0.01

0.33

0.47

Workplace size

$0.02 * *$

0.01

0.01

$-0.11$

$-0.05$

0.47

$8.45 * * *$

conditions

$-0.01 \quad-0.01$ !

$0.33 * * * \quad 0.60 * * *$

$0.36 * * *$

$0.78 * *$

0.02

0.19 ! 
Trade union at workplace:

no

Immigrant colleagues:

several

Interactions

Workplace

size*Satisfaction

Workplace size*several

immigrant colleagues

Constant

$1.89 * * *$

$1.81^{* * * *}$

$1.28 * * *$

$3.34 * * *$

$3.36 * * *$

$.49 * *$

Random-effect parameters

at context level

$0.89 *$

$0.85^{*}$

Random intercept variance 0.019 *

\section{$0.88 *$}

$0.017 *$
$-0.06^{* *}$
Variance of residual

\section{$0.97 *$}

$0.040 *$
$0.97 *$

$0.038 *$
$0.97 *$

$0.040 *$
$9.36 * * *$

$-0.10 *$

$-0.83 * * *$

$-211$

LL-ratio test of rho $=0$

13484(16) 13436(16) 12997(16)

13056(16)

$\begin{array}{llll}-18386.62 & -18016.40 & -17647.79\end{array}$

$-18335.6$

$* * *$

***

Source: Multilevel linear regression models with ESS 2002 data. Notes: $\mathrm{p}<.1, * \mathrm{p}<.05, * * \mathrm{p}<.01, * * * \mathrm{p}<.001$. 
TABLE 2

Workplace size and vote choice for new right and old right parties vis-à-vis social democrats, 2002-2010 in sixteen Western countries.

\begin{tabular}{|c|c|c|c|c|c|c|c|c|c|c|}
\hline & \multicolumn{2}{|c|}{$M 1$} & \multicolumn{2}{|c|}{$M 2$} & \multicolumn{2}{|c|}{$M 3$} & \multicolumn{2}{|c|}{ M4 } & \multicolumn{2}{|c|}{$M 5$} \\
\hline & New right & Bourgeois & New right & Bourgeois & New right & Bourgeois & New right & Bourgeois & Both right- - & ving parties \\
\hline Individual level & & & & & & & & & $\begin{array}{l}\text { For autho- } \\
\text { ritarianism }\end{array}$ & $\begin{array}{l}\text { For } \\
\text { immigration }\end{array}$ \\
\hline \multicolumn{11}{|c|}{ Class (reference category: Socio-cultural specialists) } \\
\hline Traditional bourgeoisie & $0.86 * * *$ & $0.82 * * *$ & $0.90 * * *$ & $0.86 * * *$ & $0.81 * * *$ & $0.74 * * *$ & $0.78 * * *$ & $0.78 * * *$ & $0.74 * * *$ & $0.66 * * *$ \\
\hline Technical specialists & $0.39 * * *$ & $0.25^{* * *}$ & $0.38 * *$ & $0.24 * * *$ & $0.32 * *$ & $0.17 * *$ & $0.22 !$ & $0.16^{* *}$ & $0.17 * *$ & $0.13 *$ \\
\hline Managers & $0.50 * * *$ & $0.48 * * *$ & $0.50 * * *$ & $0.48 * * *$ & $0.45 * * *$ & $0.40 * * *$ & $0.43 * * *$ & $0.40 * * *$ & $0.39 * * *$ & $0.34 * * *$ \\
\hline Petite bourgeoisie & $1.14 * * *$ & $0.82 * * *$ & $1.19 * * *$ & $0.87 * * *$ & $1.08 * * *$ & $0.74 * * *$ & $0.95 * * *$ & $0.77 * * *$ & $0.76^{* * *}$ & $0.64 * * *$ \\
\hline Production workers & $0.76^{* * *}$ & $-0.12 * *$ & $1.06 * * *$ & $0.23 * *$ & $1.02 * * *$ & $0.13 !$ & $0.71 * * *$ & 0.12 & -0.05 & $-0.19 * * *$ \\
\hline Office clerks & $0.54 * * *$ & $0.26 * * *$ & $0.54 * * *$ & $0.26 * * *$ & $0.48 * * *$ & $0.18 * * *$ & $0.38 * * *$ & $0.16 * *$ & $0.20 * * *$ & $0.15 * *$ \\
\hline Service workers & $0.66 * * *$ & $-0.09 *$ & $0.67 * * *$ & $-0.08 !$ & $0.62 * * *$ & $-0.16 * * *$ & $0.29 * *$ & $-0.18 * * *$ & $-0.08 !$ & $-0.18 * * *$ \\
\hline Male & $0.37 * * *$ & $0.06^{*}$ & $0.37 * * *$ & $0.05 *$ & $0.42 * * *$ & $0.09 * * *$ & $0.49 * * *$ & $0.09 * * *$ & $0.15^{* * *}$ & $0.16^{* * *}$ \\
\hline Age & $-0.01 * * *$ & $0.01 * * *$ & $-0.01 * * *$ & $0.01 * * *$ & $-0.01 * * *$ & $0.01 * * *$ & $-0.02 * * *$ & $0.00 * * *$ & 0.00 & $0.00 *$ \\
\hline \multicolumn{11}{|c|}{ Education (reference category: less than upper secondary) } \\
\hline Upper secondary & -0.01 & $0.19 * * *$ & -0.02 & $0.19 * * *$ & 0.02 & $0.23 * * *$ & $0.22 * * *$ & $0.25 * * *$ & $0.24 * * *$ & $0.27 * * *$ \\
\hline Post-secondary & -0.12 & $0.19 * *$ & -0.12 & $0.19 * *$ & -0.10 & $0.21 * *$ & 0.20 & $0.23 * *$ & $0.19 * *$ & $0.27 * * *$ \\
\hline Tertiary & $-0.66 * * *$ & $0.31 * * *$ & $-0.66 * * *$ & $0.31 * * *$ & $-0.63 * * *$ & $0.34 * * *$ & -0.12 & $0.40 * * *$ & $0.27 * * *$ & $0.41 * * *$ \\
\hline Union member & & & & & $-0.61 * * *$ & $-0.56 * * *$ & $-0.58 * * *$ & $-0.56 * * *$ & -0.23 & -0.10 \\
\hline Workplace size & $-0.07 *$ & $-0.10 * * *$ & -0.03 & $-0.07 * *$ & -0.01 & $-0.05^{*}$ & -0.01 & $-0.05^{*}$ & -0.04 & $-0.07 *$ \\
\hline Authoritarianism & & & & & & & & $0.01 * * *$ & $0.01 * * *$ & \\
\hline $\begin{array}{l}\text { Attitudes towards } \\
\text { immigration (positive) }\end{array}$ & & & & & & & $-0.05 * * *$ & & & $-0.02 * * *$ \\
\hline
\end{tabular}


Interactions

Production

worker*Workplace size

Union*Workplace size

Union*Cultural attitudes

Cultural attitudes

*Workplace size

Union*Workplace size*

Cultural attitudes

Constant

$-3.39 * * *$

$-0.55 * *$

$-3.48 * * *$

$-0.63 * * *$

$-3.28 * * *$

$-0.38 *$

$0.005^{*}$

$0.005^{*}$

$0.005 *$

$0.005^{*}$

$0.005^{*}$

$0.004 *$

9.90*

$0.34 *$

$10.11 *$

$0.32 *$

Random intercept variance 9.74*

$0.34 *-9.77 *$

$\mathrm{N}$

$-211$

25158(16)

40952(16)

25158(16)

40952(16)

25117(16)

$-7653.60$

40859(16)

$23287(16)$

$-26565.45$

$* * *$

$* * *$

$* * *$

$-26285.21$

$* * *$

$-6374.91$

$* * *$

Source: Multilevel logit

$* * *$

gory. ! $\mathrm{p}<.1, * \mathrm{p}<.05, * * \mathrm{p}<.01, * * * \mathrm{p}<.001$
$0.28 *$

$\begin{array}{ll}0.01 & -0.11 * \\ -0.01 ! & -0.01 * * \\ -0.00 & -0.00 \\ 0.00 & 0.00 * *\end{array}$

$-0.84 * * * \quad 1.09 * * *$

$004 * \quad 0.004 *$

$28 * 0.33 *$

077(16) 41402(16)

$-26562.63-26310.38$

**** 
TABLE 3

Summary of Hypotheses and Results

$\mathrm{H} 1$ : Employees in larger workplaces harbour more

Confirmed: especially attitudes towards unions are

positive attitudes towards unions and state

intervention since they perceive stronger antagonisms at the workplace

M3, Table 1)

$\mathrm{H} 2$ : Authoritarianism and scepticism toward

immigration is stronger in smaller workplaces with

less manifest workplace antagonisms

H3: Employees in larger workplaces are more likely

effects are mediated through workplace

antagonisms and union presence at workplace

Partly confirmed: effects for authoritarianism only

appear after controlling for workplace

antagonisms (M7-M9, Table 1); effects for

immigration confirmed (M10, Table 1) and

explained through contact with immigrants at

workplace (M11-M12, Table 1)

to support social democratic parties relative to

mainstream right and new right parties

H4: The effect of workplace size on voting choice is

larger for production workers than for other classes

H5: The right vote choice of employees and

production workers in small workplaces is explained

by stronger effects of authoritarianism and

scepticism towards immigration conditioned by

unionisation

\section{Confirmed (M2-M3, Table 2)}

Partly confirmed: authoritarianism and restrictive

views on immigration benefits right-wing parties (M4, Table 2)

Three-way interactions in M5, Table 2 indicate that workers in small workplaces base their vote

decision more strongly on cultural issues; graphic

illustration yields clear patterns for

authoritarianism which benefits right-wing

parties more strongly among non-union members

in small firms (Figure 1); weaker but similar

patterns in Figure 2 for immigration 
FIGURE 1

Effect of authoritarianism on social democratic support by plant size and union membership.
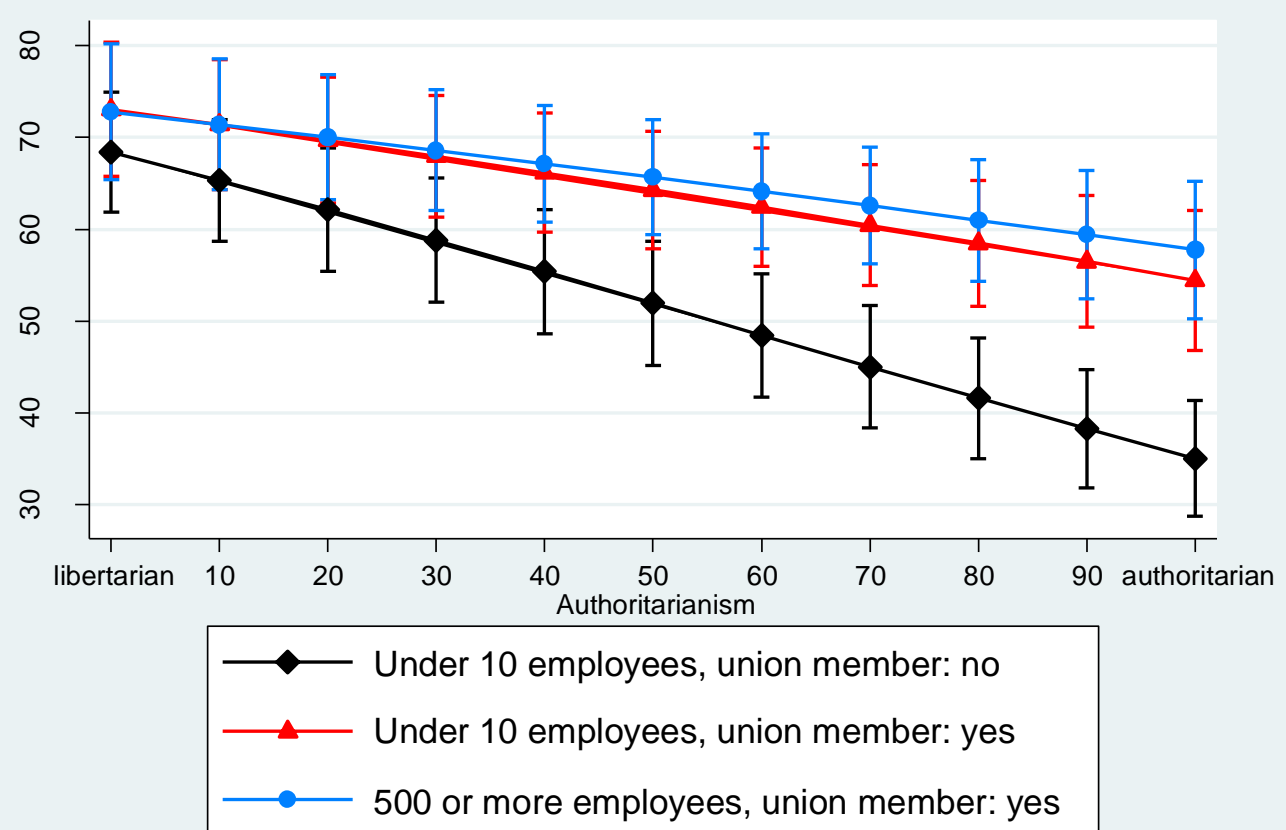

Note: Predicted probabilities for a 30 year old male production worker with less than upper secondary education Bars denote 95-percent confidence interva

Source: Model 5 from Table 2 with authoritarianism as moderator

FIGURE 2

Effect of attitudes towards immigration on social democratic support by plant size and union membership.

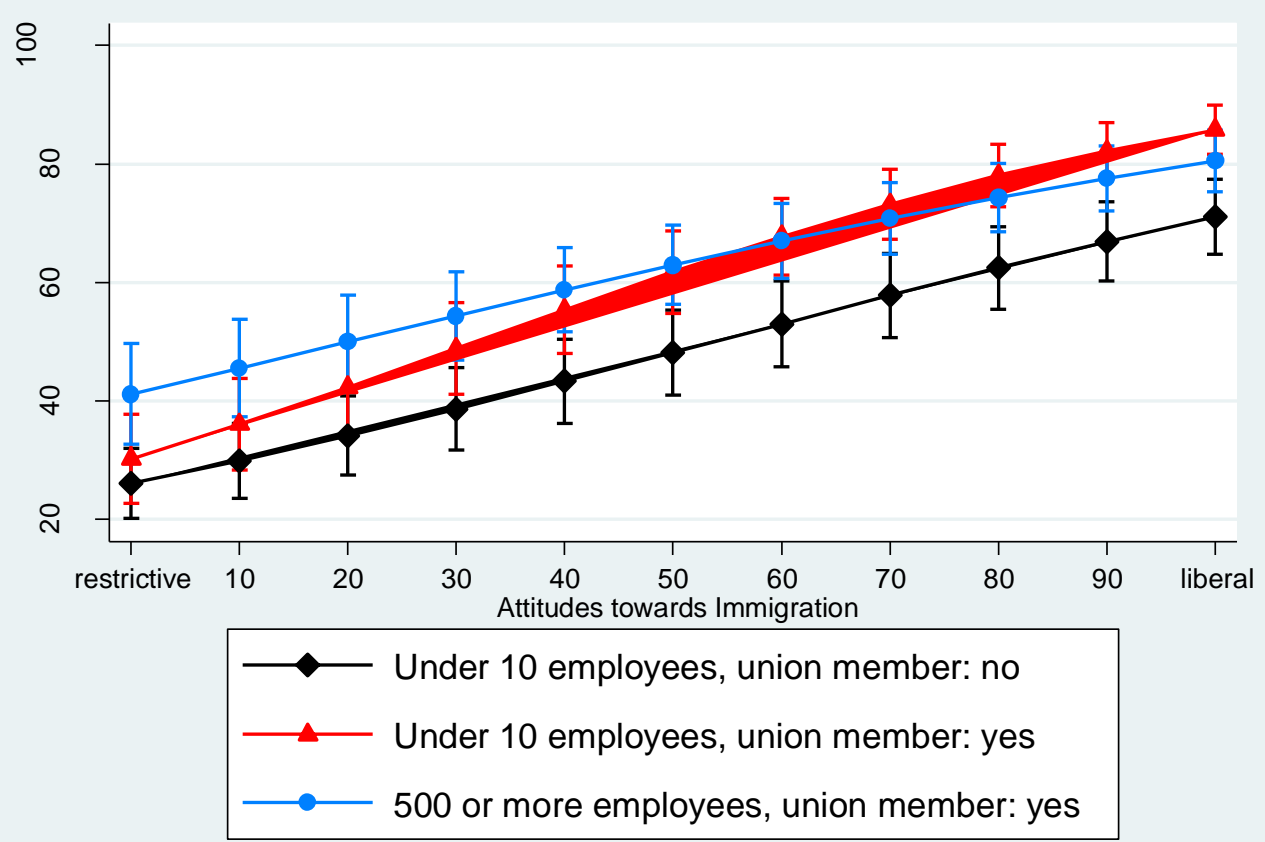

Note: Predicted probabilities for a 30 year old male production worker with less than upper seconday education Bars denote 95-percent confidence intervals

Source: Model 5 from Table 2 with immigration as moderator 


\section{Appendix}

TABLE A1

Classification of national parties into party families

\begin{tabular}{ll}
\hline Social democratic & SPÖ (Austria), SP-A, PS (Belgium), SD (Denmark), SDP (Finland), PS (France), \\
& SPD (Germany), Labour (Great Britain, Ireland), DS/La Margherita (Italy), LSAP \\
& (Luxembourg), PvdA (Netherlands), DNA (Norway), PS (Portugal), PSOE (Spain), \\
& SAP (Sweden), SPS (Switzerland) \\
\hline Old right (largest & ÖVP (Austria), CVP/CD, PSC/CDH (Belgium), Venstre (Denmark), Centre Party \\
mainstream bourgeois & (Finland), UMP (France), CDU/CSU (Germany), Conservative Party (Great Britain), \\
party) & Fianna Fáil (Ireland), Forza Italia (Italy), CSV (Luxembourg), CDA (Netherlands), \\
& Høyre (Norway), PSD (Portugal), PP (Spain), Moderaterna (Sweden), FDP \\
& (Switzerland) \\
\hline New right & FPÖ (Austria), Vlaams Blok/Belang, FN (Belgium), DF, FrP (Denmark), True Finns \\
& (Finland), FN, MNR (France), Republikaner, NPD (Germany), BNP, UKIP (Great \\
& Britain), Alleanza Nationale, Lega Nord (Italy), ADR (Luxembourg), LPF/Leefbaar \\
& Nederland, PVV, Trots op Nederland (Netherlands), FrP (Norway), Nacional \\
& Renovador (Portugal), Sverigedemokraterna (Sweden), SVP, Schweizer Demokraten \\
& (Switzerland) \\
\hline
\end{tabular}

Source: Own classification. Note: in the ESS4, the Belgian Christian Democrats also include the N-VA as the parties formed an electoral cartel.

TABLE A2

Descriptive statistics of selected variables

\begin{tabular}{|c|c|c|c|c|c|c|}
\hline & $\begin{array}{l}\text { Satisfaction } \\
\text { with the way } \\
\text { things } \\
\text { handled at } \\
\text { workplace } \\
\text { last } \\
\text { months } \\
\text { Mean of } \\
\text { Variable, } \\
\text { higher values } \\
\text { indicate more } \\
\text { satisfaction } \\
\end{array}$ & $\begin{array}{l}\text { Respondent is } \\
\text { currently } \\
\text { member of } \\
\text { trade union } \\
\text { Percentage: } \\
\text { yes }\end{array}$ & $\begin{array}{l}\text { Trade union } \\
\text { at workplace } \\
\text { Percentage: } \\
\text { yes }\end{array}$ & $\begin{array}{l}\text { Employees } \\
\text { need strong } \\
\text { trade } \\
\text { unions to } \\
\text { protect } \\
\text { their } \\
\text { working } \\
\text { conditions } \\
\text { and wages } \\
\text { Percentage: } \\
\text { Agree }\end{array}$ & $\begin{array}{l}\text { Do you have } \\
\text { any } \\
\text { colleagues at } \\
\text { work who } \\
\text { have come } \\
\text { to live in } \\
\text { [country] } \\
\text { from another } \\
\text { country? } \\
\text { Percentage: } \\
\text { No, none }\end{array}$ & $\begin{array}{l}\text { Index of } \\
\text { authoritarian } \\
\text { attitudes } \\
\text { Mean, higher } \\
\text { values } \\
\text { indicate more } \\
\text { authoritarian } \\
\text { attitudes }\end{array}$ \\
\hline $\begin{array}{l}\text { Workplace } \\
\text { size }\end{array}$ & & & & & & \\
\hline $\begin{array}{l}\text { Under } 10 \\
\text { employees }\end{array}$ & 6.67 & 10.1 & 25.7 & 67.0 & 71.6 & 66.8 \\
\hline $\begin{array}{l}\text { 10-24 } \\
\text { employees }\end{array}$ & 6.21 & 17.4 & 43.3 & 72.7 & 56.7 & 66.4 \\
\hline $\begin{array}{l}25-99 \\
\text { employees }\end{array}$ & 6.15 & 24.3 & 60.3 & 71.9 & 46.6 & 65.9 \\
\hline $\begin{array}{l}\text { 100-499 } \\
\text { employees }\end{array}$ & 5.80 & 27.4 & 77.6 & 75.0 & 37.9 & 66.2 \\
\hline 500 or more & 5.62 & 27.7 & 87.4 & 74.1 & 38.9 & 66.2 \\
\hline All & 6.14 & 19.2 & 56.3 & 71.2 & 54.8 & 66.5 \\
\hline
\end{tabular}

Source: ESS I, 2002 for first four items, ESS I-V for authoritarian attitudes, own calculations, data are weighted. 